\section{Productivity and Mineral Nutrition of Limonium Species Irrigated with Saline Wastewaters}

\author{
C. M. Grieve ${ }^{1}$ and J.A. Poss \\ U.S. Department of Agriculture, Agricultural Research Service, George E. Brown, \\ Jr., Salinity Laboratory, 450 West Big Springs Road, Riverside, CA 92507
}

\section{S.R. Grattan}

Department of Land Air and Water Resources, University of California, One Shields Avenue, Davis, CA 95616

\section{P.J. Shouse}

U.S. Department of Agriculture, Agricultural Research Service, George E. Brown, Jr., Salinity Laboratory, 450 West Big Springs Road, Riverside, CA 92507

\section{J.H. Lieth}

Department of Land Air and Water Resources, University of California, One Shields Avenue, Davis, CA 95616

\section{Zeng}

U.S. Department of Agriculture, Agricultural Research Service, Crop Genetics and Production Research, 141 Experiment Station Road, Stoneville, MS 38776

Additional index words. cut flowers, drainage water reuse, ion selectivity, salinity, sand cultures, statice, stem length

\begin{abstract}
To explore the possibility that saline wastewaters may be used to grow commercially acceptable floriculture crops, a study was initiated to determine the effects of salinity on two statice cultivars. Limonium perezii (Stapf) F. T. Hubb. 'Blue Seas' and $L$. sinuatum (L.) Mill 'American Beauty' were grown in greenhouse sand cultures irrigated with waters prepared to simulate saline drainage waters typically present in the western San Joaquin Valley (SJV) of California. Seven salinity treatments were imposed on 3-weekold seedlings. Electrical conductivities of the irrigation waters (EC) were 2.5 (control), 7 , $11,15,20,25$, and $30 \mathrm{dS} \cdot \mathrm{m}^{-1}$. Vegetative shoots were sampled for biomass production and ion analysis ten weeks after application of stress. Flower stem numbers, length, and weight were determined at harvest. Stem length of $L$. perezii was significantly reduced when irrigation water salinity exceeded a threshold of $2.5 \mathrm{dS} \cdot \mathrm{m}^{-1}$. Salt tolerance threshold based on stem length for $L$. sinuatum was $7 \mathrm{dS} \mathrm{m}^{-1}$. The species exhibited significant differences in shoot-ion relations which appear to be related to differences in salt tolerance. Sodium, $\mathrm{K}^{+}, \mathrm{Mg}^{2+}$, and total-P were more strongly accumulated in the leaves of $L$. sinuatum than $L$. perezii. Both species accumulated $\mathrm{K}^{+}$in preference to $\mathrm{Na}^{+}$, but selectivity for $\mathrm{K}^{+}$over $\mathrm{Na}^{+}$ was significantly higher in $L$. sinuatum than in the more salt-sensitive $L$. perezii. Chloride concentration in $L$. sinuatum leaves increased significantly as salinity increased, whereas the 20-fold increase in substrate-Cl had no effect on leaf-Cl in L. perezii. Both Limonium species completed their life cycles at salt concentrations exceeding $30 \mathrm{dS} \cdot \mathrm{m}^{-1}$, a character associated with halophytic plants. Maximum growth of each species, however, occurred under relatively low salt stress, and steadily declined as external salinity increased. Based on this crop productivity response, $L$. perezii should be rated as sensitive and $L$ sinuatum as moderately tolerant.
\end{abstract}

As water quality and quantity becomes limited in many parts of the world, new options are sought to make more efficient use of wastewaters in arid and semi-arid climates. Agriculture is the main user of our water sup-

Received for publication 8 Sept. 2004. Accepted for publication 5 Dec. 2004. The authors are indebted to Phyllis Nash for statistical analysis and to Donald A. Layfield for mineral ion analysis. This research was supported in part by a CAL-FED grant, administered by the California Department of Water Resources, Project Manager, Debra Gonzalez. Seed for the study were purchased from Johnny's Selected Seed, Albion, Me.

${ }^{1}$ Corresponding author. plies, therefore, strong interests and incentives have been promoted to increase the efficiency of water management through reuse options. Reuse of wastewaters would conserve greater amounts of high quality water and, at the same time, may provide a valuable resource for the production of selected floriculture crops. Because many of these high value crops are salt sensitive, growers have traditionally used good quality waters for irrigation. However, demands on high quality water supplies have increased through competition between urban and agricultural users. Growers, in many instances, must eventually rely more on low quality water resources. It becomes impor- tant, therefore, to identify floral species that will produce a commercially acceptable crop when irrigated with brackish wastewaters. This strategy, together with typical management practices that avoid excessive salinity stress in the root media, will provide the grower with an economically and environmentally sound wastewater reuse options.

Several commercially important floral and ornamental crops possess some degree of salt tolerance. Growers have exploited this variability to expand profitable cut flower industries in regions where reliable sources of high quality water are limited. Successes in breeding and selection techniques, coupled with improved methods of cultivation, have led to expansion of cut flower industries in these areas (Pasternak and Nerd, 1996). Salinity sometimes offers benefits in the production of certain floral species. Positive effects include the induction of earlier flowering, increase in the number of blooming flowers per inflorescence, and reduction of peduncle length to prevent stem collapse or drooping of the inflorescence (Shillo et al., 2002).

Many wild annual statice (Limonium sp.) are highly salt-tolerant halophytes native to saline habitats (Woodell and Mooney, 1970). In a compilation of salt-tolerant plants of the world, Aronson (1989) lists 52 Limonium species, 5 of which (including $L$. perezii and L. sinuatum) are known to complete their life cycles under hypersaline conditions, i.e., 56 $\mathrm{dS} \cdot \mathrm{m}^{-1}$. Some of the cultivated species and varieties of Limonium have retained the biochemical and physiological mechanisms and characters necessary to meet the challenges posed by moderately saline environments (Alarcon et al., 1999; Hanson et al., 1994; Morales et al., 2001). For example, irrigation water salinity up to an electrical conductivity (EC) of $11.5 \mathrm{dS} \cdot \mathrm{m}^{-1}$ had little or no effect on the number, height, or weight of flowering stems of hybrid Japanese Limonium. In this study, cultivars 'Emily Tall' and 'Emily Pink' were grown under nonsaline conditions $(\mathrm{EC}=1.8$ $\mathrm{dS} \cdot \mathrm{m}^{-1}$ ) for 7 months before the imposition of the salt treatments (Shillo et al., 2002).

Limonium is an economically valuable cut and dried flower crop. Nationwide in 1998, 234 floriculture operations produced $3.7 \times 10^{6}$ bunches of statice with a value of $\$ 4.3 \times 10^{6}$ (Census of Horticultural Specialties, 1998). The goal of this study was to grow two species [L. perezii (Stapf) F. T. Hubb. and L. sinuatum (L.) Mill.] of this commercially important crop in greenhouse sand tanks irrigated with salinesodic waters and to compare the performance of these species based on growth, yield potential, and mineral ion uptake.

\section{Materials and Methods}

Seeds of L. perezii (Stapf) F. T. Hubb. 'Blue Seas' and $L$. sinuatum L. Mill. 'American Beauty' were sown in vermiculite-filled trays on 25 Jan. (L. perezii) and 16 Mar. 2001 (L. sinuatum). Time to maturity of $L$. sinuatum (110 to $120 \mathrm{~d}$ ) is considerably shorter than that of $L$. perezii ( 180 to $200 \mathrm{~d}$ ), therefore planting dates were staggered to assure that the plants 
Table 1. Composition of salinizing salts in solutions prepared to simulate drainage waters commonly present in the San Joaquin Valley.

\begin{tabular}{lrrrrr}
\hline $\begin{array}{l}\mathrm{EC}_{\mathrm{i}} \\
\left(\mathrm{dS} \cdot \mathrm{m}^{-1}\right)\end{array}$ & \multicolumn{5}{c}{ Salinizing salt $\left(\mathrm{mol} \cdot \mathrm{m}^{-3}\right)$} \\
\cline { 2 - 6 } & $\mathrm{Ca}^{2+}$ & $\mathrm{Mg}^{2+}$ & $\mathrm{Na}^{+}$ & $\mathrm{SO}_{4}^{2-}$ & $\mathrm{Cl}^{-}$ \\
\hline 2.5 & 2.5 & 1.5 & 13.8 & 7.0 & 7.0 \\
7.0 & 7.8 & 5.5 & 50.9 & 29.5 & 24.7 \\
11.0 & 10.1 & 9.8 & 87.0 & 42.0 & 42.2 \\
15.0 & 13.0 & 13.9 & 123 & 58.2 & 59.6 \\
20.0 & 13.4 & 20.1 & 178 & 79.0 & 86.3 \\
25.0 & 13.8 & 27.9 & 247 & 104 & 111 \\
30.0 & 14.0 & 33.6 & 298 & 124 & 144 \\
\hline
\end{tabular}

flowered at about the same time. In total, 15 seedlings of $L$. perezii were transplanted into each of 21 greenhouse sand tanks in Riverside, Calif., on 8 Feb. and 15 seedlings L. sinuatum were transplanted into each of a second set of 21 tanks on 26 Mar. 2001. The tanks $(1.2 \times 0.6$ $\times 0.5 \mathrm{~m}$ deep) contained washed sand having an average bulk density of $1.7 \mathrm{Mg} \cdot \mathrm{m}^{-3}$. The sand had a volumetric water content at saturation of 0.34 and $0.1 \mathrm{~m}^{3} \cdot \mathrm{m}^{-3}$ after drainage had nearly ceased. Other water dynamics of this river sand are given in Wang(2002). Plants were irrigated three times daily with a nutrient solution consisting of $\left(\mathrm{in} \mathrm{mol} \cdot \mathrm{m}^{-3}\right): 2.5 \mathrm{Ca}^{2+}, 1.5$ $\mathrm{Mg}^{2+}, 13.8 \mathrm{Na}^{+}, 3.0 \mathrm{~K}^{+}, 7.0 \mathrm{SO}_{4}^{2-}, 7.0 \mathrm{Cl}^{-}, 3.0$ $\mathrm{NO}_{3}^{-}, 0.17 \mathrm{KH}_{2} \mathrm{PO}_{4}, 0.050 \mathrm{Fe}$ as sodium ferric diethylenetriamine pentaacetate (NaFeDTPA), $0.023 \mathrm{H}_{3} \mathrm{BO}_{3} 0.005 \mathrm{MnSO}_{4}, 0.0004 \mathrm{ZnSO}_{4}$, $0.0002 \mathrm{CuSO}_{4}$, and $0.0001 \mathrm{H}_{2} \mathrm{MoO}_{4}$ made up with Riverside municipal water. This solution, with an electrical conductivity (EC) of 2.5 $\mathrm{dS} \cdot \mathrm{m}^{-1}$, served as the control treatment. Daily irrigations were of 15-min duration, which allowed the sand to become completely saturated, after which the solution drained into $765-\mathrm{L}$ reservoirs located in a basement below the sand tanks, for reuse in the next irrigation. Water lost by evapotranspiration was replenished automatically each day to maintain constant electrical conductivities in the solutions.

Seven salinity treatments were imposed with sulfate-dominated irrigation waters designed to simulate saline wastewaters commonly present in the San Joaquin Valley of California and from predictions based on appropriate simulations of what the long-term compositions of the water would be upon further concentrations by plant-water extraction and evapotranspiration (Suarez and Simunek, 1997). Concentrations of the salinizing salts are shown in Table 1. Salinization was initiated 15
Feb. in the solutions irrigating L. perezii and on 7 Apr. for those irrigating L. sinuatum. Electrical conductivities of the saline treatments were increased to the desired levels by incremental additions of the salts over a 2-week period to avoid osmotic shock to the seedlings. Targeted $\mathrm{EC}_{\mathrm{i}}$ values of the solutions were 2.5, 7, 11, 15, 20,25 , and $30 \mathrm{dS} \cdot \mathrm{m}^{-1}$.

The $\mathrm{pH}$ was not controlled and ranged from 7.7 to 8.2 . Irrigation waters were analyzed by inductively coupled plasma optical emission spectrometry (ICPOES) to confirm that target ion concentrations were maintained. Chloride in the solutions was determined by coulometric-amperometric titration. The experiment was a randomized block design with seven salinities, two Limonium species, and three replications.

Temperature, radiation, and humidity were measured and recorded at hourly intervals at a point slightly above the plant canopy. During growth of L. perezii (8 Feb. to 1 Aug. 2001), daytime air temperatures in the greenhouse ranged from 12.2 to $36.0^{\circ} \mathrm{C}$ (mean $28.5^{\circ} \mathrm{C}$ ); nighttime temperatures were 11.1 to 31.7 ${ }^{\circ} \mathrm{C}$ (mean $22.9^{\circ} \mathrm{C}$ ). During the growth of $L$. sinuatum (26 Mar. to 1 Aug.2001), daytime air temperatures ranged from 20.0 to $36.6{ }^{\circ} \mathrm{C}$ (mean $29.0^{\circ} \mathrm{C}$ ). Daily relative humidity was the same for both periods and ranged from $42 \%$ to $48 \%$ (mean $45 \%$ )

Ten weeks after application of salt stress (24 Apr. for L. perezii and 8 May 2001 for L. sinuatum) the seedlings were still in the vegetative stage. Aboveground biomass of five plants from each tank was harvested at this time which also served to thin the plants to ten per tank. Samples were weighed, washed with deionized water, dried in a forced air oven for 1 week at $70{ }^{\circ} \mathrm{C}$, reweighed, then ground in a Wiley mill to pass a 60 -mesh screen. Total S, total $\mathrm{P}, \mathrm{Ca}^{2+}, \mathrm{Mg}^{2+}, \mathrm{Na}^{+}$and $\mathrm{K}^{+}$were determined on nitric-perchloric acid digests of the plant tissues by ICPOES. Chloride was determined on nitric-acetic acid extracts by coulometricamperometric titration.

Flower stalks of both species were harvested on 28 June, 16 July, and 1 Aug. 2001. Height and weight of stems plus inflorescence were measured.

Ion selectivity coefficients were calculated from the ratio of specific ions in the plant divided by the ratio of those ions in the medium (Flowers and Yeo, 1988). Statistical analyses were performed by analysis of variance with mean comparisons at the $95 \%$ level based on Tukey's studentized range test. SAS release version 6.12 was used (SAS Institute, Inc., 1997).

\section{Results and Discussion}

Growth and yield potential. Ten weeks after application of salinity, all seedlings survived at all treatment levels and none showed visible signs of ion toxicity or nutrient deficiency disorders. Growth of $L$. perezii rosettes was reduced by $50 \%$ as irrigation water salinity rose from 2.5 to 7 and $11 \mathrm{dS} \cdot \mathrm{m}^{-1}$, and was further reduced to $25 \%$ of the controls as salinity increased to $30 \mathrm{dS} \cdot \mathrm{m}^{-1}$ (Table 2). Limonium sinuatum plants were much more vigorous than $L$. perezii. Weights of $L$. sinuatum shoots at the same developmental stage were two to 3 -fold greater than $L$. perezii. Reduction of shoot dry matter production of L. sinuatum by salinity was not significant until the EC of the irrigation waters exceeded $15 \mathrm{dS} \cdot \mathrm{m}^{-1}$.

The Limonium species also differed in productivity based on length, fresh weight, and numbers of flowering stems (Table 2). Under nonsaline conditions, total stem count over the harvest season for L. sinuatum was 284 , twice that of L. perezii (140). Stem count per $L$. perezii plant significantly decreased from 15 to 2 as salinity increased from 2.5 to $30 \mathrm{dS} \cdot \mathrm{m}^{-1}$. In contrast, salinity had little effect on the number of stems produced by $L$. sinuatum. Stem numbers of $L$. sinuatum harvested from all salinity treatments in this greenhouse study exceeded seasonal stem number per L. sinuatum plant harvested from field trials (Armitage, 1993; Starman et al., 1995; Whipker and Hammer, 1994).

Table 2. Effect of saline-sodic irrigation waters on vegetative growth, stem length, stem fresh weight and stem numbers per plant produced by two statice species grown in greenhouse sand tanks.

\begin{tabular}{|c|c|c|c|c|c|c|c|c|}
\hline \multirow[b]{2}{*}{$\begin{array}{l}\text { Salinity } \\
(\mathrm{EC}) \\
\left(\mathrm{dS} \cdot \mathrm{m}^{-1}\right)\end{array}$} & \multicolumn{4}{|c|}{ Limonium perezii } & \multicolumn{4}{|c|}{ Limonium sinuatum } \\
\hline & $\begin{array}{l}\text { Shoot }^{2} \\
\text { dry wt } \\
\text { (g) }\end{array}$ & $\begin{array}{c}\text { Stems }^{\mathrm{y}} / \\
\text { plant } \\
\text { (no.) }\end{array}$ & $\begin{array}{c}\text { Stem } \\
\text { Length } \\
(\mathrm{cm})\end{array}$ & $\begin{array}{c}\text { Stem } \\
\text { fresh wt } \\
(\mathrm{g})\end{array}$ & $\begin{array}{l}\text { Shoot } \\
\text { dry wt } \\
\text { (g) }\end{array}$ & $\begin{array}{c}\text { Stems/ } \\
\text { Plant } \\
\text { (no.) }\end{array}$ & $\begin{array}{c}\text { Stem } \\
\text { Length } \\
(\mathrm{cm})\end{array}$ & $\begin{array}{c}\text { Stem } \\
\text { fresh wt } \\
(\mathrm{g})\end{array}$ \\
\hline 2.5 & $1.6 \mathrm{a}^{\mathrm{x}}$ & $15 \mathrm{a}$ & $62 \mathrm{a}$ & $24 \mathrm{a}$ & $3.2 \mathrm{a}$ & $32 \mathrm{a}$ & $72 \mathrm{a}$ & $25 \mathrm{a}$ \\
\hline 7 & $0.82 \mathrm{~b}$ & $9 \mathrm{~b}$ & $41 \mathrm{bc}$ & $11 \mathrm{bc}$ & $3.2 \mathrm{a}$ & $36 \mathrm{a}$ & $58 \mathrm{~b}$ & $17 \mathrm{~b}$ \\
\hline 11 & $0.83 \mathrm{~b}$ & $9 \mathrm{~b}$ & $48 \mathrm{~b}$ & $14 \mathrm{~b}$ & $2.3 \mathrm{ab}$ & $32 \mathrm{a}$ & $55 \mathrm{~b}$ & $14 \mathrm{bc}$ \\
\hline 15 & $0.59 \mathrm{~b}$ & $5 \mathrm{bc}$ & $31 \mathrm{~cd}$ & $7 \mathrm{~cd}$ & $2.7 \mathrm{ab}$ & $32 \mathrm{a}$ & $50 \mathrm{bc}$ & $13 \mathrm{bc}$ \\
\hline 20 & $0.41 \mathrm{~b}$ & $4 \mathrm{bc}$ & $26 \mathrm{~d}$ & $5 \mathrm{~d}$ & $1.4 \mathrm{~b}$ & $30 \mathrm{a}$ & $42 \mathrm{~cd}$ & $10 \mathrm{~cd}$ \\
\hline 25 & $0.40 \mathrm{~b}$ & $2 \mathrm{c}$ & $23 \mathrm{~d}$ & $4 d$ & $1.5 \mathrm{~b}$ & $27 \mathrm{a}$ & $37 \mathrm{de}$ & $7 \mathrm{~d}$ \\
\hline 30 & $0.38 \mathrm{~b}$ & $2 \mathrm{c}$ & $23 \mathrm{~d}$ & $4 \mathrm{~d}$ & $1.2 \mathrm{~b}$ & $25 \mathrm{a}$ & $30 \mathrm{e}$ & $5 \mathrm{~d}$ \\
\hline
\end{tabular}

${ }^{2}$ Shoots harvested 10 weeks after the application of salinity. Values are the means of three replications.

yStems harvested on 28 June, 16 July, and 1 Aug 2001. Values are the combined means of three replications.

${ }^{x}$ Within columns, means followed by a different letter are significantly different at the 0.05 probability level according to Tukey's studentized range test. Values are the means of three replications. 


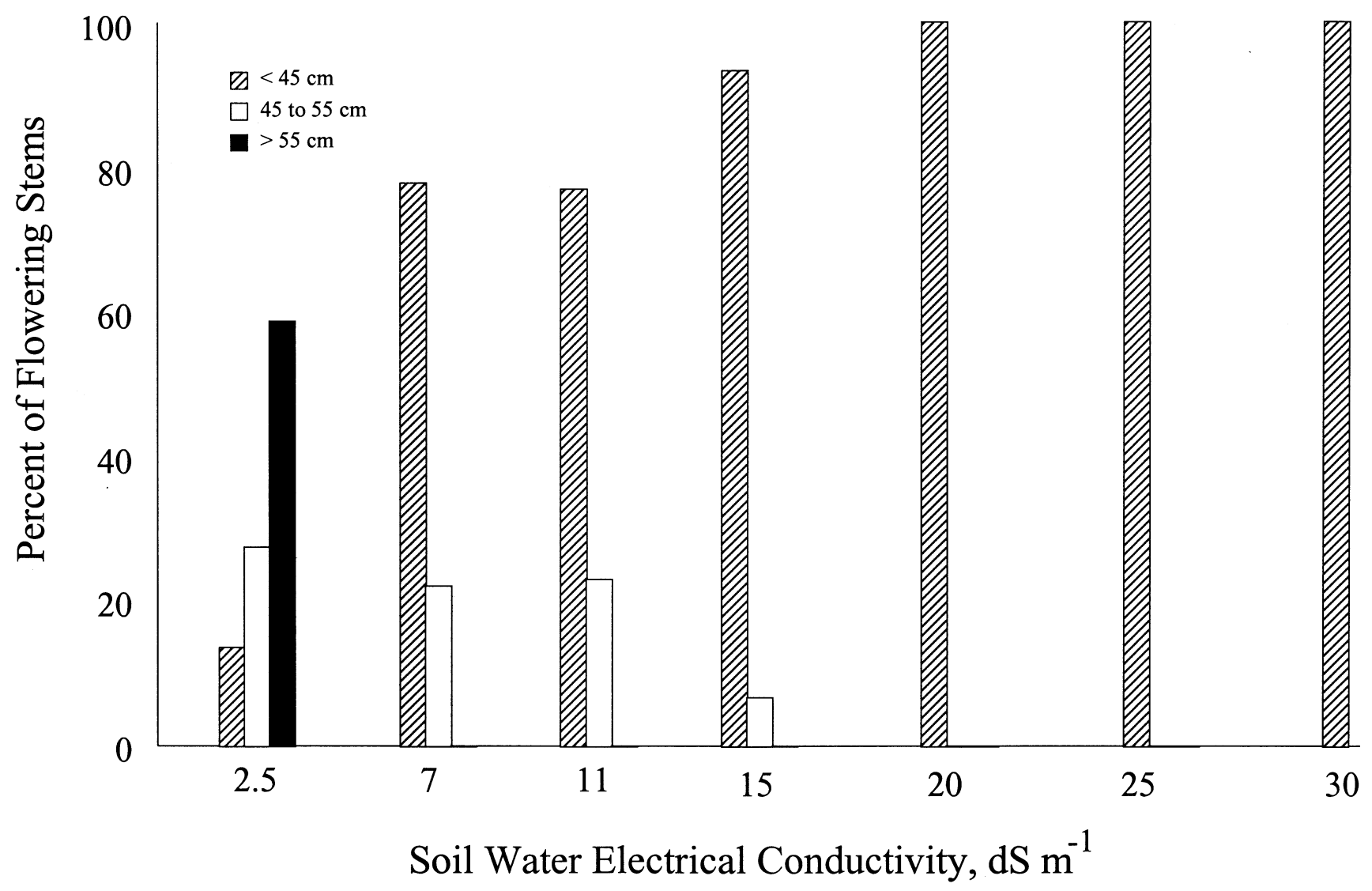

Fig. 1. Flowering stem length distribution of Limonium perezii as a function of irrigation water salinity.

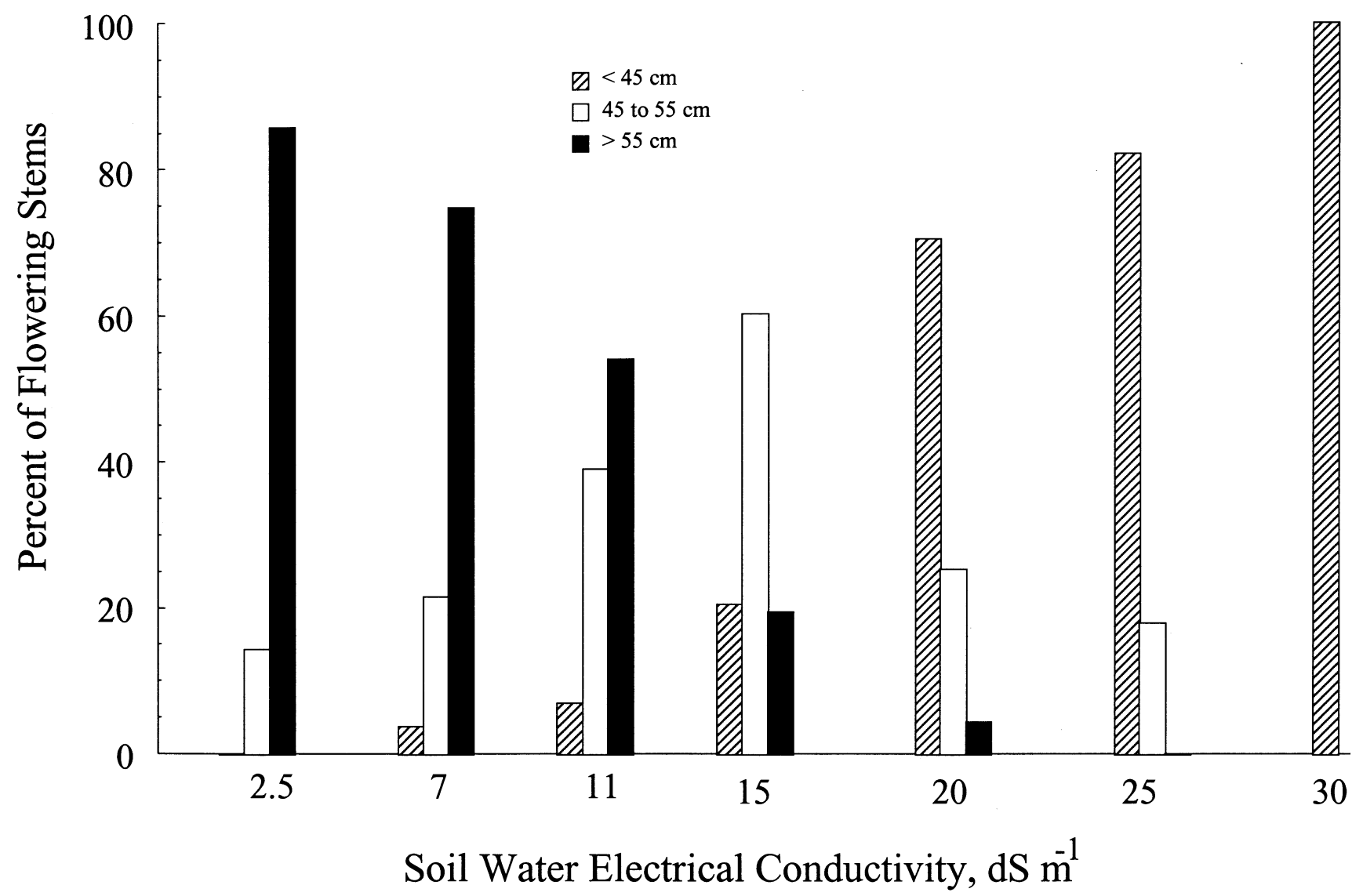

Fig. 2. Flowering stem length distribution of Limonium sinuatum as a function of irrigation water salinity. 
Stem length of both species decreased about $60 \%$ as salinity increased from 2.5 to $30 \mathrm{dS} \cdot \mathrm{m}^{-1}$ (Table 2 ). At all salinity levels, $L$. perezii produced shorter and lighter stems than L. sinuatum. Stem length distribution as a function of salinity shows that once irrigation water salinity exceeded $2.5 \mathrm{dS} \cdot \mathrm{m}^{-1}$, most L. perezii stems were $45 \mathrm{~cm}$ or less (Fig. 1), whereas $80 \%$ of $L$. sinuatum stems produced in the $15 \mathrm{dS} \cdot \mathrm{m}^{-1}$ treatment were $45 \mathrm{~cm}$ or more (Fig. 2). Height of statice cultivars grown under ideal conditions generally ranges from 61 to $76 \mathrm{~cm}$ (Armitage, 1993). Based on this quality criterion, $L$. perezii produced commercially acceptable stems only under nonsaline conditions, whereas marketable stems of $L$. sinuatum were produced by plants irrigated with both 2.5 and $7 \mathrm{dS} \cdot \mathrm{m}^{-1}$ waters. Other horticulturists suggest that the commercial standard for statice stem length is $41 \mathrm{~cm}$ (Barr, 1992; Starman et al., 1995). Accordingly, L. sinuatum and L. perezii would produce marketable stems if soil water salinities were as high as 20 and $15 \mathrm{dS} \cdot \mathrm{m}^{-1}$, respectively. Therefore, under field conditions, L. sinuatum could be safely irrigated with saline waters of $6.7 \mathrm{dS} \cdot \mathrm{m}^{-1}$, respectively, assuming the $\mathrm{EC}$ of the soil water is about twice the EC of the saturated soil paste $\mathrm{EC}_{\mathrm{e}}$ ) and a continuous leaching fraction of $15 \%$ to $20 \%$ is achieved (Ayers and Westcot, 1985).

The effect of salinity on stem fresh weight was also pronounced (Table 2). Reduction of L. sinuatum stem weight was not significant until irrigation water EC exceeded $7 \mathrm{dS} \cdot \mathrm{m}^{-1}$. In contrast, weight of $\mathrm{dS} \cdot \mathrm{m}^{-1}$ stems from the 7 $\mathrm{dS} \cdot \mathrm{m}^{-1}$ treatment was reduced by about $50 \%$.
Average stem fresh weight of our greenhousegrown L. sinuatum, 'American Beauty', was about $40 \%$ heavier than reported for the same cultivar from a field trial (Whipker and Hammer, 1994).

Both Limonium species were able to complete their life cycles at salt concentrations exceeding $350 \mathrm{~mm}\left(30 \mathrm{dS} \cdot \mathrm{m}^{-1}\right)$, clearly a halophytic trait typical of the genus (Alarcon et al., 1999; Aronson, 1989; Pasternak and Nerd, 1996). Growth response to salinity, however, more closely resembled that of glycophytic than halophytic plants. Maximum growth occurred at low salinity and decreased steadily as salt stress increased. In combination, these characters describe a class of halophytic plants (Flowers et al., 1986) termed miohalophytes (Salisbury,1995). This nomenclature is undoubtedly useful in ecophysiological studies. However, neither cultivar examined in this study possessed a high degree of salt tolerance as understood by horticulturists and agronomists whose research focuses on crop yield response to salinity (Maas and Grattan, 1999). Evaluation of the marketable yield of Limonium suggests that $L$. perezii should be rated as salt sensitive; $L$. sinuatum as moderately tolerant. Reduction in stem length should not, however, be the limiting factor in species selection for other horticultural applications. For example, 'American Beauty' and 'Blue Seas' have great value as bedding or landscape plants in problem areas. Under severe salt stress, both statice cultivars produced acceptable, healthy plants with attractive foliage and colorful inflorescences on sturdy, albeit short, stems.
Shoot-ion concentrations and interactions. The species showed unique differences in mineral ion concentration patterns in response to increasing sodium sulfate dominated-salinity (Table 3). Sodium in both species rose significantly as substrate $\mathrm{Na}$ increased. Limonium sinuatum was the stronger $\mathrm{Na}^{+}$accumulator at higher salinity levels. Shoot $\mathrm{Ca}$, in contrast, decreased about $40 \%$ as salinity increased, although $\mathrm{Ca}^{2+}$ concentration in the substrate rose from 2.5 to $14 \mathrm{~mol} \cdot \mathrm{m}^{-3}$. Reduction in shoot-Ca may have resulted from high external ratios of $\mathrm{Na}^{+} / \mathrm{Ca}^{2+}$ which limited $\mathrm{Ca}^{2+}$ availability to the plant (Suarez and Grieve, 1988). The $\mathrm{Na}^{+} / \mathrm{Ca}^{2+}$ ratios in $L$. perezii shoots generally reflected the ratios in the irrigation waters, i.e., ranging from about 5 in the control treatment to about 20 as salinity increased to $30 \mathrm{dS} \cdot \mathrm{m}^{-1}$. The $\mathrm{Na}^{+} / \mathrm{Ca}^{2+}$ range in $L$. sinuatum shoots was somewhat wider (e.g., 5 to about 29).

Patterns of shoot Mg differed between the statice species (Table 3). Magnesium concentration in L. sinuatum grown under control conditions was nearly twice as high as that in L. perezii, which may indicate a significant species difference in $\mathrm{Mg}^{2+}$ requirement. As salinity increased from 2.5 to $30 \mathrm{dS} \cdot \mathrm{m}^{-1}$ and external $\mathrm{Mg}^{2+}$ increased from 1.5 to $34 \mathrm{~mol} \cdot \mathrm{m}^{-3}, \mathrm{Mg}^{2+}$ in L. perezii shoots significantly increased, whereas L. sinuatum shoot $\mathrm{Mg}$ decreased.

The $\mathrm{K}^{+}$requirement under control conditions also appeared to be higher for $L$. sinuatum than for L. perezii. Potassium in shoots of both species decreased significantly as salinity increased (Table 3). Potassium strongly competes with $\mathrm{Mg}^{2+}$ for plant uptake. Plants with

Table 3. Effect of increasing salinity on shoot-ion concentrations in two Limonium species. Values are the means of three replications.

\begin{tabular}{|c|c|c|c|c|c|c|c|}
\hline \multirow{2}{*}{$\begin{array}{l}\text { EC } \\
\left(d S \cdot m^{-1}\right)\end{array}$} & \multicolumn{7}{|c|}{ Ion concn $\left(\mathrm{mmol} \cdot \mathrm{kg}^{-1}\right.$ dry wt) } \\
\hline & $\mathrm{Ca}^{2+}$ & $\mathrm{Mg}^{2+}$ & $\mathrm{Na}^{+}$ & $\mathrm{K}^{+}$ & Total P & Total S & $\mathrm{Cl}^{-}$ \\
\hline 2.5 & $152 a^{z}$ & $347 \mathrm{~b}$ & $781 \mathrm{~d}$ & $1017 \mathrm{a}$ & $103 \mathrm{a}$ & $334 \mathrm{~d}$ & $907 \mathrm{a}$ \\
\hline 15 & $97 \mathrm{~b}$ & $389 \mathrm{ab}$ & $1404 \mathrm{abc}$ & $575 \mathrm{bcd}$ & $72 \mathrm{bc}$ & $562 \mathrm{bc}$ & $943 \mathrm{a}$ \\
\hline 20 & $101 \mathrm{~b}$ & $452 \mathrm{ab}$ & $1707 \mathrm{a}$ & $474 \mathrm{~d}$ & $56 \mathrm{c}$ & $756 \mathrm{a}$ & $974 \mathrm{a}$ \\
\hline 25 & $82 \mathrm{~b}$ & $444 \mathrm{ab}$ & $1653 \mathrm{ab}$ & $511 \mathrm{~cd}$ & $78 \mathrm{~b}$ & $670 \mathrm{ab}$ & $1074 \mathrm{a}$ \\
\hline 2.5 & $147 \mathrm{a}$ & $671 \mathrm{a}$ & $659 \mathrm{e}$ & 1496 a & $213 b c$ & $401 \mathrm{e}$ & $983 \mathrm{c}$ \\
\hline 7 & $92 \mathrm{~b}$ & $634 \mathrm{ab}$ & $1095 \mathrm{~d}$ & $1320 \mathrm{ab}$ & $165 \mathrm{c}$ & $430 \mathrm{de}$ & $1151 \mathrm{c}$ \\
\hline 11 & $94 \mathrm{~b}$ & $530 \mathrm{~b}$ & $1760 \mathrm{bc}$ & $1231 \mathrm{bc}$ & $249 \mathrm{~b}$ & $558 \mathrm{bc}$ & $1506 \mathrm{~b}$ \\
\hline 15 & $108 \mathrm{~b}$ & $592 \mathrm{ab}$ & $1692 \mathrm{c}$ & $1175 \mathrm{bcd}$ & $198 \mathrm{bc}$ & 497 cde & 1927 a \\
\hline 20 & $81 \mathrm{~b}$ & $529 \mathrm{~b}$ & $1834 \mathrm{bc}$ & $1277 \mathrm{~b}$ & $326 \mathrm{a}$ & $549 \mathrm{bcd}$ & $1872 \mathrm{a}$ \\
\hline 25 & $77 \mathrm{~b}$ & $518 \mathrm{~b}$ & 2054 b & $1085 \mathrm{~cd}$ & $200 \mathrm{bc}$ & $660 \mathrm{ab}$ & $1727 \mathrm{ab}$ \\
\hline 3 & $85 \mathrm{~b}$ & $522 \mathrm{~b}$ & $2445 \mathrm{a}$ & $1047 \mathrm{~d}$ & $165 \mathrm{c}$ & $772 \mathrm{a}$ & $1961 \mathrm{a}$ \\
\hline
\end{tabular}

${ }^{2}$ Within columns and species, means followed by a different letter are significantly different at the 0.05 probability level according to Tukey's studentized range test. Values are the means of three replications.

Table 4. Potassium-sodium ratios and selectivity coefficients for Limonium perezii and L. sinuatum grown in greenhouse sand cultures and irrigated with salinesodic wastewaters.

\begin{tabular}{|c|c|c|c|c|c|c|c|c|}
\hline \multirow{2}{*}{$\begin{array}{l}\text { EC } \\
\left(d S \cdot m^{-1}\right)\end{array}$} & \multicolumn{4}{|c|}{ L. perezii } & \multicolumn{4}{|c|}{ L. sinuatum } \\
\hline & $\mathrm{K}^{+} / \mathrm{Na}^{+}$ & $\mathrm{S}_{\mathrm{K}, \mathrm{Na}}$ & $\mathrm{K}^{+} / \mathrm{Mg}^{2+}$ & $\mathrm{S}_{\mathrm{K}, \mathrm{Mg}}$ & $\mathrm{K}^{+} / \mathrm{Na}^{+}$ & $\mathrm{S}_{\mathrm{K}, \mathrm{Na}}$ & $\mathrm{K}^{+} / \mathrm{Mg}^{2+}$ & $\mathrm{S}_{\mathrm{K} . \mathrm{Mg}}$ \\
\hline 2.5 & $1.3 \mathrm{a}^{\mathrm{z}}$ & $6.0 \mathrm{c}$ & $3.0 \mathrm{a}$ & $1.5 \mathrm{c}$ & $2.3 \mathrm{a}$ & $11 \mathrm{c}$ & $2.2 \mathrm{a}$ & $1.1 \mathrm{~d}$ \\
\hline 70 & $0.66 \mathrm{~b}$ & $11 \mathrm{bc}$ & $1.8 \mathrm{~b}$ & $3.3 \mathrm{c}$ & $1.2 \mathrm{~b}$ & $21 \mathrm{~b}$ & $2.1 \mathrm{a}$ & $3.0 \mathrm{~d}$ \\
\hline 15 & $0.42 \mathrm{bc}$ & $17 \mathrm{~b}$ & $1.5 \mathrm{bc}$ & $6.8 \mathrm{~b}$ & $0.70 \mathrm{c}$ & $28 \mathrm{~b}$ & $2.0 \mathrm{a}$ & $9.2 \mathrm{c}$ \\
\hline 20 & $0.28 \mathrm{~d}$ & $16 \mathrm{~b}$ & $1.1 \mathrm{bc}$ & $7.1 \mathrm{~b}$ & $0.70 \mathrm{c}$ & $42 \mathrm{a}$ & $2.4 \mathrm{a}$ & $16 \mathrm{~b}$ \\
\hline 25 & $0.31 \mathrm{c}$ & $26 \mathrm{a}$ & $1.1 \mathrm{bc}$ & $11 \mathrm{a}$ & $0.53 \mathrm{c}$ & $44 \mathrm{a}$ & $2.1 \mathrm{a}$ & $20 \mathrm{a}$ \\
\hline 30 & $0.28 \mathrm{c}$ & $28 \mathrm{a}$ & $1.0 \mathrm{c}$ & $11 \mathrm{a}$ & $0.43 \mathrm{c}$ & $43 \mathrm{a}$ & $2.0 \mathrm{a}$ & $23 \mathrm{a}$ \\
\hline
\end{tabular}

${ }^{2}$ Within columns, means followed by a different letter are significantly different at the 0.05 probability level according to Tukey's studentized range test. Values are the means of three replications. 
high $\mathrm{K}^{+}$content generally require high $\mathrm{Mg}^{2+}$ in order to prevent $\mathrm{K}$-induced $\mathrm{Mg}^{2+}$ deficiency (Marschner, 1995). Potassium-magnesium relations in Limonium provide an example of the interaction. The ratio of $\mathrm{K}^{+} / \mathrm{Mg}^{2+}$ in $L$. perezii shoots decreased significantly from 3 to 1 as salinity increased, but the ratio in $L$. sinuatum was 2.2 regardless of salinity level. Foliar analysis of L. sinuatum grown under nonsaline field conditions gave an identical $\mathrm{K}^{+} / \mathrm{Mg}^{2+}$ ratio (about 2.2) (Armitage, 1993).

Species preference for $\mathrm{K}^{+}$over $\mathrm{Mg}^{2+}$ did not differ at low levels of salinity. Thereafter, $\mathrm{K}^{+}: \mathrm{Mg}^{2+}$ selectivity increased as salinity increased and was significantly higher in $L$. sinuatum than in L. perezii at all other levels of salinity (Table 4).

The ratio of $\mathrm{K}^{+} / \mathrm{Na}^{+}$in the shoots decreased as the ratio in the external solution decreased (Table 4). Many researchers suggest that the $\mathrm{K}^{+} / \mathrm{Na}^{+}$ratio in the tissues of glycophytes should be maintained above 1 to supply the $\mathrm{K}^{+}$necessary for normal functioning of metabolic processes (Ashraf, 1994; Maathuis and Amtmann, 1999). According to this criterion, the $\mathrm{K}^{+} / \mathrm{Na}^{+}$ratios for $L$. perezii and $L$. sinuatum are lower than recommended in most treatments (Table 4). Potassium was, however, preferentially acquired and transported against a strong concentration gradient of $\mathrm{Na}^{+}$, a process necessary for plant survival under saline conditions (Marschner, 1995). Both species exhibited a decided preference for $\mathrm{K}^{+}$ over $\mathrm{Na}^{+}$and selectivity coefficients $\left(\mathrm{S}_{\mathrm{K}, \mathrm{Na}}\right)$ increased with increasing salinity (Table 4). The comparatively higher salt tolerance of $L$. sinuatum relative to $L$. perezii may be the result of more effective $\mathrm{K}^{+}-\mathrm{Na}^{+}$selectivity.

Phosphorus appears to be required in higher concentrations by L. sinuatum than by $L$. perezii. Total $\mathrm{P}$ was 2 -fold higher in shoots of $L$. sinuatum than in L. perezii at all salinity levels. Phosphorus concentration in shoots of L. perezii decreased significantly as salinity increased, but this effect was not consistent in L. sinuatum shoots. The concentration of total $\mathrm{P}$ in nonsaline leaf tissue of L. sinuatum (213 $\mathrm{mmol} \cdot \mathrm{kg}^{-1}$ ) was identical to the value reported for the species grown under field conditions (Armitage, 1993).

Total $\mathrm{S}$ was strongly accumulated in shoots of both species as salinity increased and external $\mathrm{SO}_{4}$ rose from 7 to $124 \mathrm{~mol} \cdot \mathrm{m}^{-3}$. Shoot S concentrations in the Limonium species equaled or exceeded those found in well-known active $\mathrm{S}$ accumulators such as cruciferous vegetables grown under irrigation with saline-sodic waters of the same ionic composition (Grieve et al., 2001). In response to a $23 \mathrm{dS} \cdot \mathrm{m}^{-1}$ treatment, total-S in tatsoi (Brassica rapa L.), mustard greens (B.juncea L.), and kale (B. oleraceae L.) was 396,371 , and $515 \mathrm{mmol} \cdot \mathrm{kg}^{-1}$ dry weight, respectively. Irrigation with saline waters (20 $\mathrm{dS} \cdot \mathrm{m}^{-1}$ ) of the same composition resulted in $756 \mathrm{mmol}$ total $\mathrm{S}$ in L. perezii and $540 \mathrm{mmol}$ total $\mathrm{S} / \mathrm{kg}$ in L. sinuatum.

Another striking species difference in ion relations was in shoot $\mathrm{Cl}$ concentrations in 10-week-old seedlings. Generally, plant $\mathrm{Cl}$ increases proportionally with increases in external $\mathrm{Cl}$. However, as salinity increased and external $\mathrm{Cl}$ rose from 7 to $144 \mathrm{~mol} \cdot \mathrm{m}^{-3}, \mathrm{Cl}^{-}$in L. sinuatum shoots doubled, but the effect of the 20-fold increase in substrate $\mathrm{Cl}$ was not significant for $L$. perezii. Various other species also exhibit a similar response whereby large increases in substrate $\mathrm{Cl}$ do not result in significant increases in plant $\mathrm{Cl}$. The effect has been observed when certain plants are grown under irrigation with sodium-sulfate dominated waters, e.g., the saline drainage effluents present in the SJV which typically contain equimolar ratios of $\mathrm{Cl}^{-}$to $\mathrm{SO}_{4}^{2-}$. For example, 14-fold increases in external- $\mathrm{Cl}$ resulted in significant increases in $\mathrm{Cl}^{-}$concentration in aboveground biomass of pac choi (B rapa L.), kale, and spinach (Spinacia oleracea $\mathrm{L}$.), but shoot $\mathrm{Cl}$ content of endive (Cichorium endivia L.), radicchio (C. intybus L.) and swiss chard (Beta vulgaris L.) was not significantly affected (Grieve et al., 2001). These response may illustrate a competitive inhibition of $\mathrm{Cl}^{-}$uptake and/or transport by $\mathrm{SO}_{4}{ }^{2-}$. White and Broadley (2001) point out that under saline conditions, anion channels in the plasma membrane facilitate $\mathrm{Cl}^{-}$uptake. The channels are also permeable to other physiological anions $\left(\mathrm{NO}_{3}^{-}, \mathrm{SO}_{4}^{2-}\right)$ which may limit $\mathrm{Cl}^{-}$transport to the shoot. Inhibition of shoot- $\mathrm{Cl}$ accumulation by this process, however, did not appear to confer salt tolerance. Limonium sinuatum, the more salt tolerant of the two species, was an active $\mathrm{Cl}^{-}$accumulator whereas the salt sensitive $L$. perezii tended to restrict $\mathrm{Cl}^{-}$concentration in the shoots.

The overall conclusions of this study are 1) the ability of a plant to survive and complete its life cycle under highly saline conditions does not necessarily confer a high level of salt tolerance based on yield; 2) quality of the marketable product indicates that $L$. perezii is salt sensitive, whereas $L$. sinuatum is moderately tolerant; 3) high selectivity of $\mathrm{K}^{+}$over $\mathrm{Na}^{+}$may have contributed to enhanced tolerance of $L$. sinuatum; and 4) the differential response in shoot $\mathrm{Cl}$ accumulation from substrates containing high levels of $\mathrm{SO}_{4}{ }^{2-}$ and $\mathrm{Cl}^{-}$warrants further investigation.

\section{Literature Cited}

Alarcon, J. J., M. A. Morales, A. Torrecillas, and M. J. Sánchez-Blanco. 1999. Growth, water relations and accumulation of organic and inorganic solutes in the halophyte Limonium latifolium cv. Avignon and its interspecific hybrid Limonium caspia $\times$ Limonium latifolium $\mathrm{cv}$. Beltlaard during salt stress. J. Plant Physiol. 154:795-801.

Armitage, A.M. 1993. Speciality cut flowers, 372 p. Varsity Press/Timber Press, Portland, Ore.

Aronson, J.A. 1989. HALOPH. A data base of salt tolerant plants of the world. Office of Arid Lands Studies, Univ. Arizona, Tucson.

Ashraf, M. 1994. Breeding for salinity tolerance in plants. Crit. Rev. Plant Sci. 13:17-42.

Ayers, R.S. and D.W. Westcot. 1985. Water quality for agriculture. FAO Irr. Drainage Paper 29 Rev. 1.

Barr, C. 1992. The kindest cuts of all: How to evaluate new crops. Greenhouse Mgr. 11:82-84.

Census of Horticultural Specialties. 1998. Cut flowers sold by state, p. 167-181. 97/horticulture/horticulture.htm.

Flowers, T.J., M.A. Hajibagheri, and N.J.W. Clipson. 1986. Halophytes. Quart. Rev. Biol. 61:313-337.

Flowers, T.J. and A.R. Yeo. 1988. Ion relations of salt tolerance, , p. 392-416. Chapter 10. In: D.A. Baker and J.L. Hall (eds.). Solute transport in plant cells and tissues. John Wiley \& Sons, New York.

Grieve, C.M., M.C. Shannon, and J.A. Poss. 2001. Mineral nutrition of leafy vegetable crops irrigated with saline drainage water. J. Veg. Crop Prod. 7:37-47.

Hanson, A.D., B. Rathinasabopathi, J. Rivoal, M. Burnet, M.O. Sillon and D.A. Gage. 1994. Osmoprotective compounds in the Plumbaginaceae: A natural experiment in metabolic engineering of stress tolerance. Proc. Natl. Acad. Sci. USA 91:306-310.

Maas, E.V. and S.R. Grattan. 1999. Crop yields as affected by salinity, p. 55-108. In: R.W. Skaggs and J.van Schilfgaarde (eds.). Agricultural drainage. Amer. Soc. Agron. Monogr. 38.

Maathuis, F.J.M. and A. Amtmann. 1999. $\mathrm{K}^{+}$nutrition and $\mathrm{Na}^{+}$toxicity: The basis of cellular $\mathrm{K}^{+} / \mathrm{Na}^{+}$ nutrition. Ann. Bot. 84:123-133.

Marschner, H. 1995. Mineral nutrition of higher plants. Academic Press, New York

Morales, M.A., E. Olmos, A. Torrecillas, M.J. Sánchez-Blanco, and J.J. Alarcón. 2001. Differences in water relations, leaf ion accumulation and excretion rates between cultivated and wild species of Limonium sp. grown in conditions of saline stress. Flora 196:345-352.

Pasternak, D. and A. Nerd. 1996. Research and utilization of halophytes in Israel, p. 325-348. In: R. Choukr-Allah, C.V. Malcolm, and A. Hamdy (eds.). Halophytes and biosaline agriculture. Marcel Dekker, New York.

Salisbury, F.B. 1995. Units, symbols, and terminology for plant physiology, Utah State Univ., Logan.

SAS Institute, Inc. 1997. SAS/STAT software: Changes and enhancements through release 6.12. SAS Inst., Cary, N.C.

Shillo, R., M. Ding, D. Pasternak, and M. Zaccat. 2002. Cultivation of cut flower and bulb species with saline water. Sci. Hort. 92:41-54.

Starman, T.W., T.A. Cerny, and A.J. MacKenzie. 1995. Productivity and profitability of some field-grown specialty cut flowers. HortScience 30:1217-1220.

Suarez, D.L. and C. M. Grieve. 1988. Predicting cation ratios in corn from saline solution composition. J. Expt. Bot. 39:605-612.

Suarez, D. L. and J. Simunek. 1997. UNSATCHEM: Unsaturated water and solute transport model with equilibrium and kinetic chemistry. Soil Sci. Soc. Amer. J. 61:1633-1646.

Wang, D. 2002. Dynamics of soil water and temperatures in above ground sand cultures used for screening plant salt tolerance. Soil Sci. Soc. Amer. J. 66:1484-1491.

Whipker, B.E. and P.A. Hammer. 1994. Growth and yield characteristics of field-grown Limonium sinuatum (L.) HortScience 29:638-640.

White, P.J. and M.R. Broadley. 2001. Chloride in soils and its uptake and movement within the plant: A review. Ann. Bot. 88:967-988.

Woodell, S.R.J. and H.A. Mooney. 1970. The effect of seawater on carbon dioxide exchange by the halophyte Limonium californicum (Boiss.) Heller. Ann. Bot. 34:117-121. 